\title{
https://doi.org/10.46813/2021-136-034 \\ TWO-PARAMETRIC BEAM MODEL FOR DOSIMETRY OF THE PROCESS OF ELECTRON IRRADIATION OF MATERIALS WITH LOW DENSITY AND ATOMIC NUMBER
}

\author{
V.T. Lazurik', V.M. Lazurik', G. Popov' ${ }^{1}$, Z. Zimek ${ }^{2}$ \\ ${ }^{1}$ V.N. Karasin Kharkiv National University, Kharkov, Ukraine; \\ ${ }^{2}$ Institute of Nuclear Chemistry and Technology, Warsaw, Poland \\ E-mail: lazurik@hotmail.com
}

\begin{abstract}
The work is devoted to studying the possibility of using a two-parametric model of an electron beam to describe the depth distributions of the electron dose in materials with a low density and an effective atomic number. In this model, the parameters are determined by fitting the semi-empirical model (PFSEM-method) to the results of measurements of the depth-dose distribution in a dosimetric wedge. The depth-dose distributions in a birchwood wedge were measured at the Institute of Nuclear Chemistry and Technology in Warsaw, Poland. The parameters of the electron beam incident on the wedge were determined by the PFSEM method. The Monte Carlo simulations of the depth-dose distribution in the wedge for the process of electron irradiation, the characteristics of which are determined by the PFSEM method, have been carried out. It is shown that there is a satisfactory agreement between the measurement results and the Monte Carlo simulation of the depth-dose distribution. The advantages of describing depth-dose distributions in a wedge based on a two-parametric model of an electron beam in comparison with traditional methods of polynomial approximation of measurement results are discussed.
\end{abstract}

PACS: 87.53.Bn

\section{INTRODUCTION}

The practical use of a dosimetric wedge in radiation technologies is regulated by international standards, which define the procedures for measuring the depth distribution of the dose in the wedge, methods for processing the measurements and interpreting the results of processing measurements $[1,2]$. The standards propose to determine the most probable energy $\boldsymbol{E}_{\boldsymbol{P}}$ and the average energy $\boldsymbol{E}_{\boldsymbol{A} \boldsymbol{v}}$ of electrons in the beam using the dosimetric wedge method. These characteristics of electrons in a beam are widely used to control the stability of the electron radiation flux in radiation-technological processes. However, the characteristics of electron radiation obtained using a standard dosimetric wedge, in some cases, are unsuitable for describing the spatial distribution of the dose in irradiated objects. Indeed, the spatial distribution of the dose substantially depends on the density and the effective atomic number of the materials of the irradiated objects. As a rule, during radiation sterilization of medical devices and foodstuffs, the density and effective atomic number of materials of irradiated objects are several times lower than for aluminum, on the basis of which a standard dosimetric wedge is made. In addition, for materials with low density, the spatial distribution of the dose in the irradiated objects depends significantly on the angular distribution of electrons in the beam. Therefore, for the further development of radiation technologies, dosimetric wedges created on the basis of materials with low density and effective atomic number are of interest.

A modern method for determining the characteristics of electron radiation is based on measurements of the depth distribution of the dose in a dosimetric wedge and using the parametric fitting method of the semiempirical model (PFSEM method) [3 - 5]. This method has proven itself well in radiation sterilization technologies in which aluminum dosimetric wedges are used [6 9]. In connection with the above, an urgent scientific and practical task is to test the PFSEM method using the results of measurements in dosimetric wedges created from materials with low density and effective atomic number.

Therefore, for the further development of radiation technologies, dosimetric wedges created on the basis of materials with low density and effective atomic number are of interest, which was carried out at the radiation sterilization line of the Institute of Nuclear Chemistry and Technology in Warsaw, Poland [10]. The advantages of describing depth dose distributions in a wedge on the basis of a semiempirical model with parameters calculated by the PFSEM method in comparison with traditional methods of polynomial approximation of measurement results are discussed.

\section{DEPTH-DOSE CURVE OF ELECTRON RADIATION IN A BIRCH WEDGE}

Measurements of the depth-dose curve of electron radiation were carried out using dosimetric films located in a wedge made of birch wood. The characteristics of the wedge are as follows:

- density of birch wood: $0.536 \mathrm{~g} / \mathrm{cm}^{3}$;

- effective atomic number: 6.28 ;

effective atomic weight: 11.86 ;

dimensions: $12.5 \times 46.5 \times 45.5 \mathrm{~cm}$;

slope factor: 0.265 .

The method of irradiation and processing of dosimetric films is described in [6, 7].

The measurement results are shown in Fig. 1. The dose value $\boldsymbol{D}(\boldsymbol{x})$ is normalized to the calculated dose value $\boldsymbol{D}(\boldsymbol{\theta})$ on the wedge surface onto which the electron beam falls. The depth in the wedge $\boldsymbol{X}$ is indicated in standard mass units of length $\left[\mathrm{g} / \mathrm{cm}^{2}\right]$. The vertical dashed lines indicate the boundaries of the depth regions that are used in the radiation sterilization process. Mark $\boldsymbol{X}_{\boldsymbol{I}}$ indicates the depth range that is used for single-sided irradiation and $\boldsymbol{X}_{2}$ for double-sided irradiation. For com- 
parison, in Fig. 1 shows the depth-dose curve of electrons in the birch wedge, calculated using a semiempirical model [5], the parameters of which were determined by the PFSEM method.

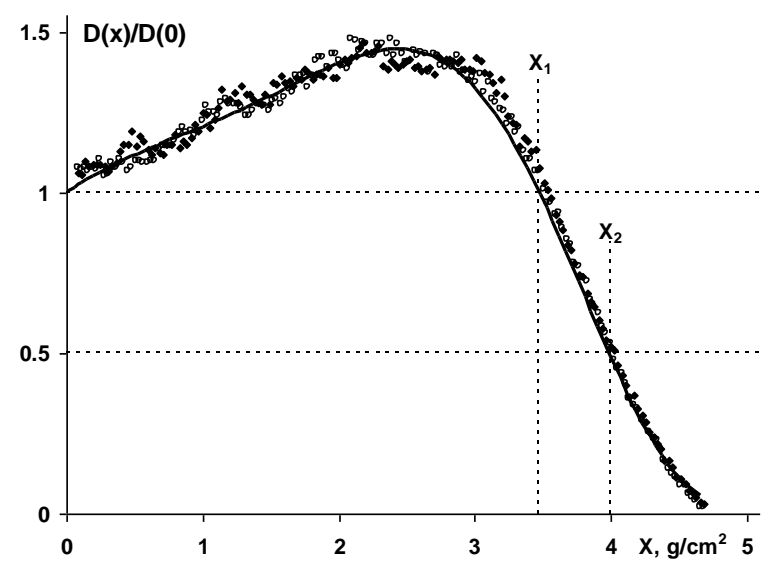

Fig. 1. Dose distribution by depth in a wedge of birch. Points - results of measurements, a continuous curve approximation of measurements by the PFSEM method

When characterizing electron radiation by the PFSEM method, the absolute values of the measured dose are not used and, therefore, the method error is determined only by the reproducibility of measurement. Estimates of the reproducibility standard deviation of measurements $\boldsymbol{\Delta}$ were made on the basis of calculating the standard deviation of the dose values measured on the first $\boldsymbol{D}_{\boldsymbol{I}}\left(\boldsymbol{x}_{i}\right)$ and second $\boldsymbol{D}_{2}\left(\boldsymbol{x}_{i}\right)$ dosimetry films, for each of the recorded depths $\boldsymbol{x}_{i}$. For the areas of depths defined by marks $X_{1}$ and $X_{2}$, the estimates of the rootmean-square measurement errors are close and do not exceed values of $2 \%$. As seen from Fig. 1, the error in approximating the measurement results using the PFSEM method is comparable to the error in the measurements

\section{PROCESSING OF MEASUREMENT RESULTS BY USING THE PARAMETRIC FITTING METHOD OF THE SEMI- EMPIRICAL MODEL}

The processing of the results of dose measurements on two dosimetric films by the PFSEM method was carried out. For each of the films, using the PFSEM method, the model parameters of the electron beam of the radiation sterilization line, corresponding to the measurement results, were calculated. Model parameters of the electron beam calculated from the measurement data for the first $\boldsymbol{E} \boldsymbol{x}_{1}$ and the second $\boldsymbol{E} \boldsymbol{x}_{2}$ films are presented in Table. The line $\boldsymbol{A} \boldsymbol{v}_{-} \boldsymbol{E} \boldsymbol{x}$ shows the model parameters of the electron beam obtained for the averaged data from these two measurements.

The results of fitting the parameters of the semi-empirical model of the depth distribution of the dose of electron beam to the measurement results

\begin{tabular}{|l|c|c|r|}
\hline & $\begin{array}{c}\boldsymbol{E}_{\boldsymbol{1}} \\
{[\mathrm{MeV}]}\end{array}$ & $\begin{array}{c}\boldsymbol{E}_{\boldsymbol{0}} \\
{[\mathrm{MeV}]}\end{array}$ & $\begin{array}{c}\boldsymbol{X}_{\boldsymbol{0}} \\
{\left[\mathrm{g} / \mathrm{cm}^{2}\right]}\end{array}$ \\
\hline $\boldsymbol{E} \boldsymbol{x}_{\boldsymbol{1}}$ & 8.67 & 8.71 & 0.016 \\
\hline $\boldsymbol{E} \boldsymbol{x}_{\boldsymbol{2}}$ & 8.7 & 8.82 & 0.056 \\
\hline $\boldsymbol{A} \boldsymbol{v}_{-} \boldsymbol{E x}$ & 8.69 & 8.77 & 0.037 \\
\hline
\end{tabular}

As can be seen from Table and Fig. 1, the model parameter of the displacement $\boldsymbol{X}_{\boldsymbol{0}}$ is small in comparison with the depths and the use of dose distributions in radiation technologies. This indicates the correct choice of the starting point when processing the depth distribution of the dose on the films. Note, that there is a small difference in the model energy parameters for the oneparameter fit $\boldsymbol{E}_{\boldsymbol{1}}$ and two-parameter fit $\boldsymbol{E}_{\boldsymbol{0}}$ of the data obtained in these two measurements.

The test results of the PFSEM method are illustrated in Fig. 2. In the figure, the dots show the values of the dose distribution averaged over two measurements. The solid curve is an approximation of the averaged values of the dose distribution using the PFSEM method and computer visualization of the semi-empirical model of the depth distribution of the absorbed energy of an electron beam in matter [5]. Histogram - calculation using the ModeRTL software module of the RT-Office system [11] in accordance with the values of the characteristics of electron radiation $\boldsymbol{E}_{\boldsymbol{0}}=8.77$ and $\boldsymbol{X}_{\boldsymbol{0}}=0.037$ determined by the PFSEM method (see Table 1) within the framework of the two-parameter model of the electron beam [7].

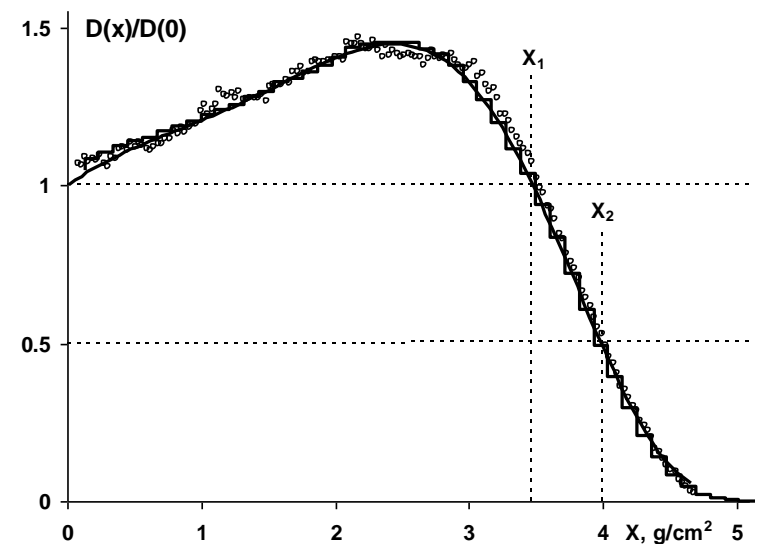

Fig. 2. Comparison of measurement and calculation results using the PFSEM method. Points-average depth distribution of the dose over two measurement results, a continuous curve - approximation of measurements by the PFSEM method, histogram - calculation using ModeRTL module of the RT-Office system

As seen in Fig. 2 satisfactory agreement:

- between the measurement values and the calculation results, using a computer visualization of a semiempirical model [5] of the depth dose distribution in a wedge of birch wood irradiated with an electron beam, the parameters of which were determined by the PFSEM method;

- between the measurement values and the calculation results, using Monte Carlo simulation [11] of the depth dose distribution in a wedge of birch wood irradiated with an electron beam, the parameters of which were determined by the PFSEM method.

\section{POLYNOMIAL APPROXIMATION OF MEASUREMENT RESULTS}

A numerical study of the possibilities of determining the dependences of the depth dose distribution on the basis of traditional methods of polynomial approximation of the measurement results was carried out. Some 
results of the numerical study of the polynomial approximation of measurements of the depth distributions of the electron radiation dose in a wedge made of birch wood are shown in Figs. 3 and 4.

As can be find in Fig. 3 the dashed curve is the approximation by a polynomial of the 2 nd degree, the dashed-dotted curve is the approximation by the polynomial of the 3rd degree and the dashed curve is the approximation by the polynomial of the 4th degree. Solid curve according approximation by the PFSEM method.

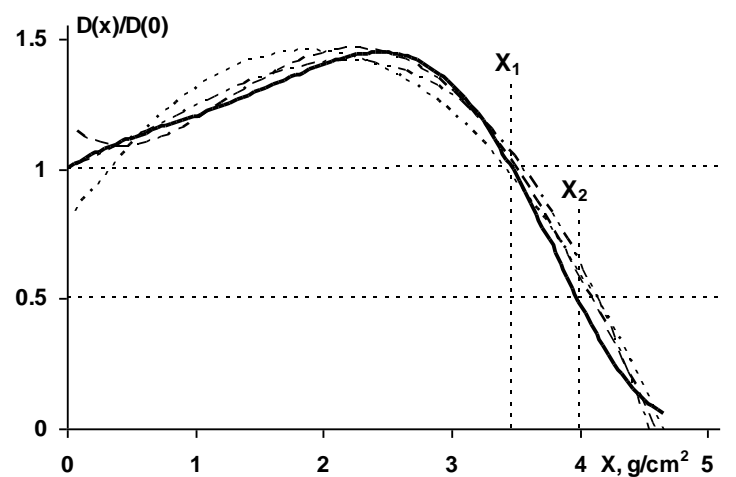

Fig. 3. Comparison of approximations of measurement results by polynomials of different degrees

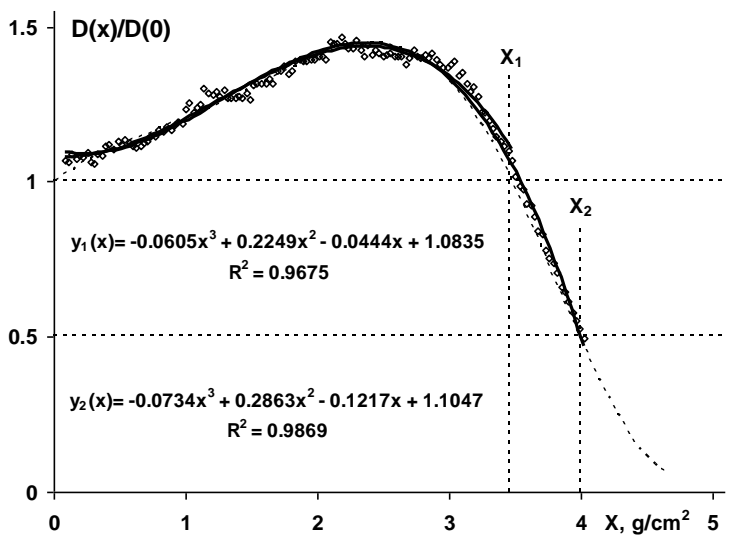

Fig. 4. Comparison of approximations of measurement results by degree 3 polynomials and using the PFSEM method. Points - measurement results, continuous curves - approximation by polynomials of degree 3, a dashed curve-approximation of measurements by the PFSEM method

According to that:

- the results of measurements of dose distributions in the depth ranges $\left(0-X_{1}\right)$ and $\left(0-X_{2}\right)$ cannot be approximated by polynomials below the 3rd degree with an accuracy comparable to the accuracy of the measurements;

- polynomial approximation of measurement results cannot provide correct extrapolation to determine the dose value on the wedge surface, on which the electron beam falls.

\section{CONCLUSIONS}

Comparison of the depth dose distributions obtained as a result of measurements and calculations based on the parameters of the electron beam determined by the using the parametric fitting method of the semiempirical modelallows us to draw the following conclusions:
- the error in approximating the results of measurements of the depth dose distribution in a birch wood dosimetric wedge, made by the PFSEM method, is comparable to the error in the measurements;

- there is satisfactory agreement between the results of measurements and Monte Carlo calculation of the depth distribution of the dose of electron radiation, the characteristics of which were determined by the PFSEM method;

- in the depth ranges of practical interest, approximation of the results of measurements of the depth distribution of the dose by polynomials above the 3rd degree allows us to describe the depth distribution of the dose with an accuracy comparable to the accuracy of the measurements

- the approximation of the results of measurements of the depth dose distribution performed by the PFSEM method coincides with the accuracy comparable with the accuracy of the polynomial approximation of these measurement results.

Thus, the using the parametric fitting method of the semi-empirical model allows one to satisfactorily describe the results of measurements of depth dose distributions using only two characteristics of the electron beam, in contrast to the polynomial approximation for which at least four formal parameters are required.

\section{REFERENCES}

1. ISO/ASTM Standard 51649. Practice for Dosimetry in an E-Beam Facility for Radiation Processing at Energies between $300 \mathrm{keV}$ and $25 \mathrm{MeV}$, Annual Book of ASTM Standards. 2005, v. 12.02.

2. Radiation Dosimetry: Electron Beams with Energies between 1 and $50 \mathrm{MeV}$, International Commission on Radiation Units and Measurements. 1984, report 35, Bethesda, MD, USA.

3. V.T. Lazurik, A.V. Pochynok. Dosimetry of electrons on the base of computer modeling the depthdose distribution of irradiation, Journal of Kharkiv University //Mathematical modeling. Information technologies series. 2010, № 925, p. 114-122.

4. A.V. Pochynok, V.T. Lazurik, G.E. Sarukhanyan. The parametric method of the determination of electron energy on the data obtained by the method of a dosimetric wedge // Bulletin Kherson National Technical University. 2012, v. 2(45), p. 298-302.

5. V.M. Lazurik, T. Tabata, V.T. Lazurik. A Database for Electron-Material Interactions // Radiation Physics and Chemistry. 2001, v. 60, p. 161-162.

6. V.T. Lazurik, V.M. Lazurik, G. Popov, Z. Zimek. Determination of electron beam parameters on radiation-technological facility for simulation of radiation processing // East Eur. J. Phys. 2014, v. 1(3), p. 7478.

7. V.T. Lazurik, V.M. Lazurik, G. Popov, Z. Zimek. Two-parametric model of electron beam in computational dosimetry in radiation processing // Radiation Physics and Chemistry. 2016, v. 124, p. 230-234.

8. V.T. Lazurik, V.M. Lazurik, G. Popov, Z. Zimek. Method of Dosimetry Based on a Two-Parametric Model of Electrons Beam for Radiation Processing // Problems of Atomic Science and Technology. 2017, v. 112(6), p. 137-141. 
9. V.T. Lazurik, V.M. Lazurik, G. Popov, Z. Zimek. Determination of the average absorbed energy of electrons beam in objects at radiation processing // Problems of Atomic Science and Technology. 2019, v. 124(6), p. 134-137.

10. J. Bigolas, S. Kulinski, W. Maciszewski, M. Pachan, E. Plawski, Z. Zimek. Current approach to design of high-power electron accelerators to match actual requirements of radiation technology in Poland // $\mathrm{Ra}$ - diation Physics and Chemistry. 2001, v. 60, p. 161162.

11. V.T. Lazurik, V.M. Lazurik, G. Popov, Yu. Rogov, Z. Zimek. Information system and software for quality control of radiation processing / Book. 232 p. IAEA: Collaborating Center for Radiation Processing and Industrial Dosimetry, Warsaw, Poland. 2011.

Article received 12.10 .2021

\section{ДВУХПАРАМЕТРИЧЕСКАЯ МОДЕЛЬ ПУЧКА ДЛЯ ДОЗИМЕТРИИ ПРОЦЕССА ЭЛЕКТРОННОГО ОБЛУЧЕНИЯ МАТЕРИАЛОВ С МАЛЫМИ ПЛОТНОСТЬЮ И АТОМНЫМ НОМЕРОМ}

\section{В.Т. Лазурик., В.М. Лазурик, Г. Попов, З. Зимек}

Работа посвящена исследованию возможности использования двухпараметрической модели электронного пучка для описания распределения дозы электронов по глубине в материалах с низкой плотностью и эффективным атомным номером. В этой модели параметры определяются путем подгонки полуэмпирической модели (PFSEM-метод) к результатам измерений распределения дозы по глубине в дозиметрическом клине. Распределение дозы по глубине в клине из березовой древесины было измерено в Институте ядерной химии и технологий в Варшаве, Польша. Параметры падающего на клин электронного пучка определялись методом PFSEM. Проведено моделирование методом Монте-Карло распределения дозы по глубине в клине для процесса электронного облучения, характеристики которого определены методом PFSEM. Показано, что существует удовлетворительное согласие между результатами измерений и моделированием методом Монте-Карло распределения дозы по глубине. Обсуждаются преимущества описания распределения дозы по глубине в клине на основе двухпараметрической модели электронного пучка по сравнению с традиционными методами полиномиальной аппроксимации результатов измерений.

\section{ДВОПАРАМЕТРИЧНА МОДЕЛЬ ПУЧКА ДЛЯ ДОЗИМЕТРІЇ ПРОЦЕСУ ЕЛЕКТРОННОГО ОПРОМІНЕННЯ МАТЕРІАЛІВ 3 НИЗЬКИМИ ЩІЛЬНІСТЮ І АТОМНИМ НОМЕРОМ}

\section{В.Т. Лазурик, В.М. Лазурик, Г. Попов, З. Зимек}

Робота присвячена дослідженню можливості використання двопараметричної моделі електронного пучка для опису розподілу дози електронів по глибині в матеріалах з низькою щільністю і ефективним атомним номером. У цій моделі параметри визначаються шляхом підгонки напівемпіричної моделі (PFSEM-метод) до результатів вимірювань розподілу дози по глибині в дозиметричному клині. Розподіл дози по глибині в клині з березової деревини було виміряно в Інституті ядерної хімії та технологій в Варшаві, Польща. Параметри падаючого на клин електронного пучка визначалися методом PFSEM. Проведено моделювання методом Монте-Карло розподілу дози по глибині в клині для процесу електронного опромінення, характеристики якого визначені методом PFSEM. Показано, що існує згода між результатами вимірювань і моделюванням методом Монте-Карло розподілу дози по глибині. Обговорюються переваги опису розподілу дози по глибині в клині на основі двопараметричної моделі електронного пучка в порівнянні з традиційними методами полиномиальной апроксимації результатів вимірювань. 